\title{
DIFFERENT URBAN CONSOLIDATION CENTRE SCENARIOS: IMPACT ON EXTERNAL COSTS OF LAST-MILE DELIVERIES
}

\author{
Marko VELIČKOVIĆ, Đurđica STOJANOVIĆ, Svetlana NIKOLIČIĆ, Marinko MASLARIĆ \\ Dept of Traffic Engineering, Faculty of Technical Sciences, University of Novi Sad, Serbia
}

Received 4 June 2015; revised 18 February 2016; accepted 18 April 2016; published online 4 September 2017

\begin{abstract}
The identification and mitigation of negative externalities from goods deliveries in urban areas are important aspects of sustainable urban development. Previous studies have shown that urban freight consolidation increases the load factor of Delivery Vehicles (DVs), reducing the vehicle-kilometres driven and thus reducing negative freight transport externalities in urban areas. The objective of this paper is to explore the possible impact of the number of Urban Consolidation Centres (UCCs) on the external costs of last-mile deliveries in freight transport and to determine the possible contribution of such consolidation scenarios to external cost mitigation. Therefore, several consolidation scenarios are considered assuming different numbers of UCCs in operation. A new consolidation scheme is proposed with more than one UCC to serve a given city area. Input data are obtained from a roadside questionnaire survey with a sample of 1617 drivers at 9 access roads to an urban area as part of the NOvi Sad TRAnsport Model (NOSTRAM) study. Externalities are calculated using the IMPACT methodology and discussed for different urban freight consolidation options. The best option is identified, and the results indicate that properly planned, organised and managed urban freight consolidation can significantly reduce transport externalities. The main research results showed that all of the proposed consolidation options increase the total driving distance in an urban area. However, some consolidation options significantly reduce the driving distance of less manageable vehicles in last-mile deliveries (long-haul heavy- and light-duty vehicles). Consequently, the external costs ranged from 2108.3 to 5420.5 EUR for the consolidation option, whereas the current state externalities are 2791.4 EUR. Thus, more small UCCs may provide better results than the central centre even in medium-sized cities.
\end{abstract}

Keywords: urban consolidation centres, transport externalities, urban freight delivery, city logistics, medium-sized cities, Novi Sad, Serbia.

\section{Notations}

DV - Delivery Vehicle;

GDP - Gross Domestic Product;

HCV - Heavy Commercial Vehicle;

LCV - Light Commercial Vehicle;

LHV - Long-Haul Vehicle;

NOSTRAM - NOvi Sad TRAnsport Model;

$\mathrm{O}-\mathrm{D}$ - Origin-Destination;

UCC - Urban Consolidation Centre;

$V$ - type of vehicle;

$F$ - fuel type;

$P$ - period of the day;

$O$ - chosen consolidation option;

$i$ - number of city entrance points;

$j$ - number of final delivery points;

$l$ - number of consolidation points; $c$ - type of externality;

$T^{V F P}$ - origin-destination matrix for vehicle type $V$, fuel type $F$ and period of the day $P$;

$T_{1}^{V F P}$ - origin-centre matrices for vehicle type $V$, fuel type $F$ and period of the day $P$;

$T_{2}^{O}$ - centre-destination matrices for consolidation option $O$;

$D$ - distance matrix from the city entrance point to the final delivery point;

$D_{1}^{O}$ - distance matrices for chosen consolidation option $O$ from city entrance point $i$ to the location of the closest consolidation centre $l$;

$D_{2}^{O}$ - distance matrices for chosen consolidation option $O$ from the location of consolidation centre $l$ to the final delivery point $j$;

$E C_{c}^{V F P}$ - external cost matrices for externality $c$, vehicle type $V$, fuel type $F$ and period of the day $P$;

\footnotetext{
${ }^{*}$ Corresponding author. E-mail: marvel@uns.ac.rs
} 
$E C_{c}^{1}$ - external cost matrices for externality $c$, from the city entrance point $i$ to the location of the consolidation centre $l$;

$E C_{c}^{2}$ - external cost matrices for externality $c$, from the location of consolidation centre $l$ to the final delivery point $j$;

$e_{c}^{V F P}$ - unit external cost for externality $c$, vehicle type $V$, fuel type $F$ and period of the day $P$;

$e_{c}^{P}-$ unit external cost of chosen DV $v$ for externality $c$ and period of the day $P$.

\section{Introduction}

The problems generated by freight transportation in urban areas are increasing due to the higher population densities, higher demands for goods, higher expectations and increased congestion, pollution and noise. There is a need to conduct freight-related traffic analyses from a new perspective to find the best possible solutions for sustainable cities.

In many developing economies, the majority of freight transport is undertaken by road-based vehicles (Bhattacharya et al. 2014). The concept of city logistics is introduced to manage freight flows in an urban environment. Wolpert and Reuter (2012) described various interpretations of city logistics by different authors. A major problem for city logistics is the utilisation of freight vehicles in urban areas. More efficient utilisation can be achieved by the consolidation of freight in UCCs (Ehmke 2012). Additionally, the European Commission has funded various projects and provided handbooks and best practice guides to address city logistics issues (e.g., Dablanc 2011; Allen et al. 2007). Better utilisation and shorter average distances of urban freight vehicles are likely to reduce the externalities of freight transport in urban areas. The objective of this paper is to explore the possible impact of different number of UCCs on the external costs of freight transport in a particular environment and to contribute to this body of knowledge.

The remainder of this paper is organized as follows. The theoretical background is briefly presented in Section 1. The research methodology is described in Section 2, and the main research results are presented and discussed in the Sections 3 and 4, respectively. Finally, the conclusion with closing remarks is presented in the last section.

\section{Research background}

External cost arises when the social or economic activities of one group of persons have an impact on another group and when that impact is not fully accounted or compensated for by the first group (EC 2003). External costs can be classified into two groups: main costs and secondary costs. The main external costs are as follows (Gallo 2010):

- greenhouse gas emissions - greenhouse gases (e.g., $\mathrm{CO}_{2}, \mathrm{CH}_{4}, \mathrm{H}_{2} \mathrm{O}, \mathrm{N}_{2} \mathrm{O}, \mathrm{O}_{3}$ ) are naturally present in the atmosphere and are therefore not assumed to be pollutants from a technical perspective. However, the high concentration of these gases (mainly $\mathrm{CO}_{2}$ ) increases the greenhouse effect, increasing the average temperature of the planet, with serious climatic consequences;

- air pollution - transportation engines emit certain pollutants (e.g., $\mathrm{SO}_{2}, \mathrm{NO}_{\mathrm{x}}, \mathrm{PM}_{10}, \mathrm{CO}$ ) into the atmosphere. High concentrations of these gases damage human health, buildings and cultivations;

- noise - transportation systems are noise sources. In addition to disturbances, the noise produces health damage to residents in the more exposed zones;

- accidents - transportation accidents, mainly caused by road systems, are an important social problem. The costs produced by accidents are assumed to be nearly entirely external because the users do not perceive the accident risk and because the accident costs fall prevalently on others, e.g., the pain and suffering imposed on others;

- congestion - the increment of transportation costs due to congestion is not captured by the price system, so the congestion costs are assumed to be external, even if they are borne by users; these costs can be estimated by quantifying the users' lost time.

The following secondary costs are emphasized: water and soil pollution, landscape and nature damage, upstream and downstream effects, visual intrusion, separation effects, and soil occupancy (Gallo 2010).

Internalisation, often referred to as the 'user pays' and 'polluter pays' principle (Van den Bossche et al. 2012; Van Essen et al. 2012), supports the standpoint that each transport user has to pay the full social costs (both private and external) associated with each transport operation (Forkenbrock 1999). A comprehensive infrastructure charging scheme implementation by the EU and Member States is required to internalise external costs (EC 1995; MDS Transmodal Limited 2012).

The external costs can form a significant portion of the total cost when considered in a logistics network (Ansbro, Wang 2013). According to certain studies, goods movement represents between 20 and $30 \%$ of vehicle-kilometres and between 16 and $50 \%$ of the emission of air pollutants by transport activities in a city (e.g. Dablanc 2007; Filippi et al. 2010; Allen et al. 2012b). The inclusion of related external costs in transportation pricing could increase the price of such a service but could conversely induce a need to reduce these costs. Thus, external costs have to be included in cost-benefit analyses in planning and decision-making processes but are often neglected.

In this paper, we evaluated the possible impact of urban freight consolidation centres on transport externalities in a particular environment. UCCs are widely used as physical facilities in city logistics proposals and developments (Crainic et al. 2009a; Janjevic et al. 2013). The literature suggests that UCCs have the ability to both improve supply chain performance and reduce local environmental and traffic problems within urban areas (Allen et al. 2012b). Even in cases where urban 
store deliveries are currently efficiently organized from a retail chain perspective, this is not typically the case from a city perspective (Van Rooijen, Quak 2010). UCCs can benefit society, local authorities and wider business interests, and a range of other value-added logistics and retail services can also be provided (Browne et al. 2005; Lewis et al. 2010; Marcucci, Danielis 2008; Russo, Comi 2010).

Authors in the literature have used different terms for urban freight consolidation facilities, such as city distribution centres (Crainic et al. 2009b), urban freight terminals (Dablanc 2007), urban freight consolidation centres (Marcucci, Danielis 2008), and the term used here, UCCs. The broad definition of UCCs, proposed by Browne et al. (2005) and subsequently adopted by many other authors, is as follows: 'A UCC is a logistic facility that is situated in relatively close proximity to the geographic area that it serves, be that a city centre, an entire town or a specific site (e.g., shopping centre), from which consolidated deliveries are carried out within that area'. We also assumed that UCCs include all initiatives that use a facility, in which flows from outside the city are consolidated with the objective to bundle inner-city transportation activities (Van Rooijen, Quak 2010).

The given definition also suggests a classification for UCCs. However, various UCC classification schemes are proposed in the literature and in practice. UCCs may vary in number, size, purpose and locations in the cities that introduce them due to particular city characteristics and freight flow characteristics. UCCs can serve a single company or be multi-company UCCs; they can be dedicated either for the entire city or, more commonly, specific urban districts (Browne et al. 2007). However, the distinction between UCCs serving a district rather than an entire town is difficult to determine from the literature (ibid.). A more comprehensive classification that combines operation types and the geographical area served proposes three main groups of UCCs (Browne et al. 2007; Allen et al. 2012b): UCCs serving all or part of an urban area, UCCs serving large sites with a single landlord, and construction project UCCs. The first type of UCC is the most widespread and is mainly related to the supply of retail products and food supplies for restaurants and cafes. UCCs may also differ in size and service range. Service diversification may vary from transshipment and relatively basic consolidation and delivery services to a wider range of value-added logistics activities (ibid.). However, many UCCs focus only on retail operations and distribution chains. They can also be divided into interurban or suburban depots, which serve to separate logistics activities inside and outside of a city (De Assis Correia et al. 2012), or small 'satellites' (Crainic et al. 2004) dedicated to serving a particular urban area, such as micro-distribution centres, transshipment points, or mobile logistic facilities (Browne et al. 2011; Janjevic et al. 2013). The former may be used in combination with the latter, forming a multi-tier urban consolidation scheme; for example, urban distribution centres transform interurban flows into urban flows, and satellites serve particular areas with small, environmen- tally friendly vehicles. This two-tier system has a rationale only in large cities with high population densities, where it can significantly reduce the number of truck$\mathrm{km}$ and truck-hours in an urban area (Crainic et al. 2004, 2009a; Browne et al. 2011). Finally, UCCs can be served by a single carrier or multiple carriers (GonzalezFeliu et al. 2014).

In theoretical analyses, the UCC appeared to be successful in many cases, but in practice, the concept has failed many times. Many reasons may cause the low profitability of UCCs implemented in a real environment. The main concern for failing UCCs is their efficiency and the long-term profitability of the centre (Van Duin et al. 2012), typically related to low throughput (Gonzalez-Feliu et al. 2014; Allen et al. 2012b). Allen et al. (2012b) argue that UCC success depends strongly on its type and implementation conditions. To be profitable, some researchers propose that UCCs must receive subsidies, at least for the initial investment and operational costs (Janjevic et al. 2013), whereas Verlinde et al. (2012) argue that the short life of UCCs is directly related to their dependence on government subsidies. Van Duin et al. (2010) recognized several factors in seven Western European cities. The reasons for the failures included a shortage of stakeholders, poor choice of UCC location in combination with an inadequate or conventional urban distribution fleet, necessity for public funding even after a trial period, low usage of the full UCC capacity, organization of the UCCs (Van Duin et al. 2010), and collaboration challenges between competitors (Gonzalez-Feliu et al. 2014). Van Duin et al. (2010), Browne et al. (2005) and the BESTUFS report (Allen et al. 2007) also emphasize the importance of choosing an appropriate UCC location.

Furthermore, concepts that were successful in highincome economies do not necessarily work in a developing country. UCC schemes have been more prevalent in high-income European countries, with the majority of feasibility studies, trials and operational schemes in the UK, Germany, France, Italy and the Netherlands (Allen et al. 2012b; Konstantinopoulou 2010), although some evidence of good practice is also recorded in other European countries (e.g. Rose-Cherasi 2012). Given the relatively low success rate of UCCs to date, especially in mainland Europe, any applications must be specific, with well-understood objectives, a clear understanding of the nature and volume of the traffic to be handled and a pre-determined and measurable set of criteria (Browne et al. 2007).

In short, establishing successful and financially viable UCCs is influenced by the city characteristics. City size, number of inhabitants and population density, geographic area, and commercial and industrial land use patterns affect the types and quantities of goods produced and consumed and therefore the total quantity of freight transport handled and the distances over which goods are moved (Allen et al. 2012a). The logistics management of road freight transport operations are affected by geographical location, topography, infrastructure and overall land use patterns and trade imbalances. In 
turn, the logistics influence the efficiency of road freight journeys (i.e., the ratio of tonne-kilometres to vehiclekilometres) to, from and within urban areas and thus external costs. Because a city is a complex, costly and highly constrained space, warehouse facilities are typically shifted toward the periphery, whereas the cities are mainly spaces of circulation and unloading and loading (Dablanc 2007; Allen et al. 2012a). Restricted areas and urban road layouts (e.g., narrow streets) may also impact the need for UCCs in suburban areas, where HGVs should be replaced with LGVs for last-mile shipments (ibid.).

Numerous research papers address different types of UCCs, their implementation problems and their generated environmental benefits in cities (Browne et al. 2011; Van Duin et al. 2010; Van Rooijen, Quak 2010; Russo, Comi 2012), but few papers study the effects of introducing more than one centre to serve an urban area, especially with regard to external costs of transport. Some authors argue that use of only one UCC has not been successful for large cities (Dablanc 2007), although it is difficult to estimate a city size boundary for introducing more than one UCC. A single large facility generates more vehicle-kilometres and thus more externalities and related costs. Herzog (2011) noted that it could be an unsuitable solution to concentrate all of the cross-docking activities into one enormous facility because it would cause long-haul traffic arriving from the opposite direction of the city to go through or around the urban area. Conversely, this solution creates economies of scale that may be of key importance for UCC success. Gonzalez-Feliu and Salanova Grau (2014) noted that it is a strategic decision for a public authority to establish more than one UCC.

We have not found a research paper that considers the impact of introducing several UCCs on the transport externalities in medium-sized cities. To explore the impact of the UCC concept on transport externalities in greater depth, we consider the freight transport external costs for different numbers of UCCs in operation in a 'what-if' framework. We include the options with one or more UCCs; the latter option is typically overlooked in the related literature.

\section{Methodology}

A case study is a good method for exploring the described problem. The case study in this research is the Novi Sad city, an administrative, cultural, economic, industrial, educational and scientific centre of the Serbian North Province Vojvodina. Recently, the city has recorded significant mechanical growth due to the sociopolitical and economic changes in Serbia and the region. Today, with more than 300,000 inhabitants in the urban area and a population density of 526 inhabitants $/ \mathrm{km}^{2}$ (Statistical Office of the... 2012), Novi Sad attracts significant freight flows, whereby road transport has a dominant role compared to other modes of transport. According to the master plan of Novi Sad, the population density is considered to be "high density-low to me- dium rise. This city is also one of the largest construction sites in the region (Kostreš, Atanacković-Jeličić 2011). In addition to the urban part of the city, there are 12 more settlements and 1 town in the municipal area. Some of the suburbs have grown over the years and physically merged with the city. The dominating industries in Novi Sad are agriculture, information technologies, water management, commerce and processing industries. The city is located on the key European motorway network corridor route E-75 and on the Danube river banks. Novi Sad also has the river port, where many industrial facilities and a free trading zone are located. The administrative area of Novi Sad is $702.7 \mathrm{~km}^{2}$, and the urban area of $129.7 \mathrm{~km}^{2}$ is built mainly on flat terrain and partially on the slopes of Fruška Gora Mountain. The spatial dispersion of the city and specific densification of the city core-area are expected to continue in the future. The possible future growth of the urbanized area also raises other questions regarding sustainable development - environmental problems, ecosystem fragmentation, energy consumption and the relationship between capacity and the quality of space (Kostreš, Atanacković-Jeličić 2011). However, the vast majority of city municipality plans do not include logistics that impact environmental problems and, in particular, external freight transport costs.

In Novi Sad, city traffic planners implemented a high restriction for the entry of heavy vehicles (with a gross weight of more than 5 tonnes) into the wider centre of the city ('city ring') (Stojanović et al. 2011). There are several studies and research papers addressing the goods delivery and hub location problems in the urban area of Novi Sad (Javno preduzeće 'Urbanizam' 2004; Veličković et al. 2011). These studies suggest that the current location of the Port of Novi Sad is the best solution for the logistics centre construction for many reasons, but external costs were not considered in the decision-making process. Previous traffic studies in Novi Sad with regard to external costs (Basaric et al. 2015) were related to passenger traffic, whereas freight transport was neglected.

For research purposes, the city districts were defined according to earlier research of transport in Novi Sad (Veličković et al. 2014). Possible locations for road freight UCCs are proposed with regard to the following concerns:

- proximity to the border line of the urban area to intercept vehicles before they enter the city;

- the positions of city access roads and intersections;

- interurban freight flow intensity from the main directions;

- proximity to an appropriate delivery route;

- urban land use plans.

Based on these principles, we have identified three possible locations for UCCs, which are used in further analysis. The first location is in the Western part of the city, the second is in the north, and the third is in the southeast part of the city (see Figure). Every location is dedicated to serving certain city entrance roads (illustrated with black arrows), and delivery routes are as- 
sumed to be easily managed from each one. The impact of consolidation is evaluated only with regard to the external costs; no other costs are considered (e.g., capital and investment costs, operation costs).

The local road traffic database, developed under the NOSTRAM (Javno preduzeće 'Urbanizam' 2009), is used as the input for the calculations. This database lacks systematic data on inner city freight deliveries and time series. A roadside questionnaire survey was conducted with a sample of 1617 freight vehicle drivers at 8 access roads to the urban area (red dots in Figure). To obtain more reliable samples of freight flows, one additional location was included in the survey: a level crossing at a road-rail bridge where large freight flows occur. The questionnaire form contains 7 carefully designed questions regarding the type of vehicle, trip start point, trip end point, quantity of goods in the vehicle, type of goods, purpose of the trip and frequency of driving on the current route. The data gained from the questionnaire survey were mainly used to determine the $\mathrm{O}-\mathrm{D}$ pairs and related quantity of goods. A traffic counting for data enlargement was conducted in conjunction with the questionnaire survey. Traffic counting was performed at all 8 access roads to the urban area, resulting in 53693 vehicles coming in and out of the urban area, of which $11 \%$ were freight vehicles.

In the following equations $V \in\{\mathrm{LCV}, \mathrm{HCV}\}$ indices for the type of vehicle, $F \in\{$ diesel, gasoline $\}$ indices for the fuel type, $V \in$ \{day peak, day off-peak, night $\}$ indices for the period of the day, $i \in\{1,2, \ldots, 8\}$ indices for the number of city entrance points and $j \in\{1,2, \ldots, 10\}$ indices for the number of city districts where the goods are transported.

Freight transportation matrices (Equation (1)) were obtained in a similar manner as in Güler (2014):

$$
T^{V F P}=\left[\begin{array}{ccc}
t_{11} & \ldots & t_{1 j} \\
\cdot & \cdot & \cdot \\
t_{i 1} & \cdots & t_{i j}
\end{array}\right] .
$$

The routes are estimated by an all-or-nothing assignment technique - the simplest route choice method with an assumption that all of the drivers consider the same attributes for the route choice. This method is considered to be appropriate for assigning freight vehicles in Novi Sad because there is a city act regulating the paths reserved for such vehicles and truck drivers do not have many path options. After the routes are assigned, the necessary distances are determined, the average trip lengths are calculated for every O-D pair, and the matrices are obtained (Equation (2)):

$$
D=\left[\begin{array}{ccc}
d_{11} & \ldots & d_{1 j} \\
\cdot & \cdot & \cdot \\
d_{i 1} & \cdots & d_{i j}
\end{array}\right] .
$$

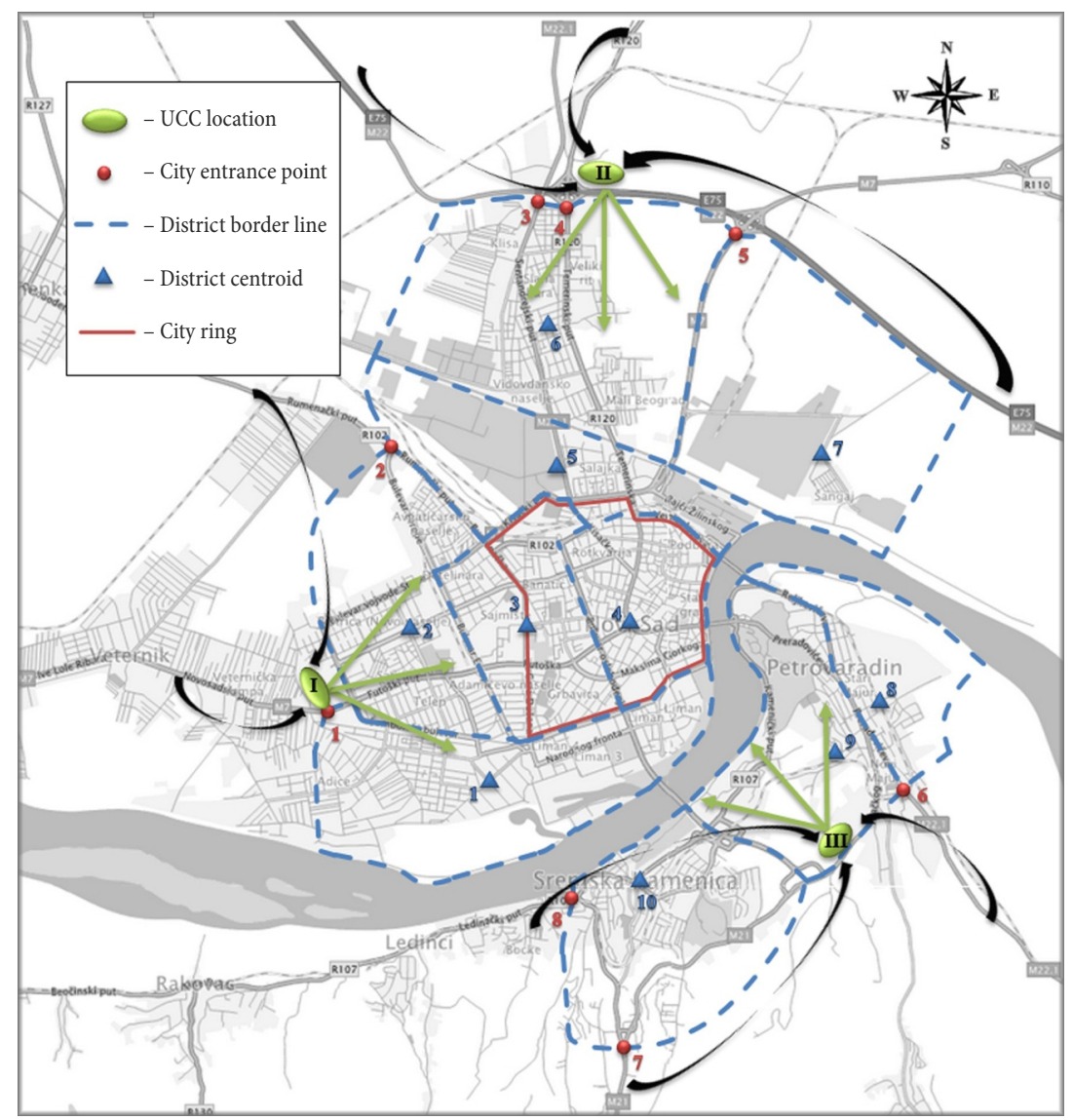

Figure. Map with the proposed UCC locations in the city of Novi Sad 
The main external costs were calculated based on the IMPACT methodology given in Handbook on estimation of external costs in the transport sector (Korzhenevych et al. 2014; Maibach et al. 2008). The majority of the secondary external costs (landscape and nature damages, visual intrusion, separation effects, soil occupancy) are not included in this research because they produce less important effects that are difficult to quantify. A transparent value transfer mechanism, GDP per capita, was used to transfer general unit cost values. The Hadamard product, also known as the element-wise product, was used to multiply the freight transportation with the distance matrices, and it is multiplied by a scalar unit external cost (Equation (3)). The grand sum of all of the matrix elements obtained with Equation (3) gives the value of a particular externality.

$$
E C_{c}^{V F P}=\left(T^{V F P} \circ D\right) e_{c}^{V F P} .
$$

Seven consolidation scenarios are suggested with different numbers of UCCs:

- option A - freight distribution with one operating UCC ( 3 possibilities): $A_{I}-$ UCC at location I; $A_{I I}-$ UCC at location II; $A_{I I I}-$ UCC at location III;

- option $B$ - freight distribution with two operating UCCs (3 possibilities): $B_{I+I I}$ - UCCs at locations I and II; $B_{I+I I I}-$ UCCs at locations I and III; $B_{I I+I I I}-$ UCCs at locations II and III;

- option C - simultaneous operation of all three UCCs: $C_{I+I I+I I I}$.

When consolidation occurs, LHVs are assigned to the closest consolidation centre, where goods are sorted, consolidated and loaded onto DVs. A commodity-based gravity model is used, combined with a loading model to convert the tonnes of goods into the number of DV trips (Gentile, Vigo 2013). The assumption in this paper is that all of the goods from UCCs are delivered only with 3.5-ton LCVs $v$; among the potential impacts of UCCs, only load factor improvements are considered in this paper. Utilisation of DVs is set to $80 \%$, which is the result of implementing an urban distribution centre in the city centre of Kassel (Panebianco, Zanarini 2005). Introducing break-bulk points $l \in\{1,2,3\}$ between city entrance points $i$ and final delivery points $j$ transformed the prior $\mathrm{O}-\mathrm{D}$ matrices and distance matrices based on the chosen consolidation option $O \in\left\{A_{I}, A_{I I}, A_{I I I}, B_{I+I I}\right.$, $\left.B_{I+I I I}, B_{I I+I I I}, C_{I+I I+I I I}\right\}$ on two levels:

- LHV O-D matrices (Equation (4)) and distance matrices (Equation (6)) from city entrance point $i$ to UCC location $l$ with regard to the UCC proximity;

- DV O-D matrices (Equation (5)) and distance matrices (Equation (7)) from UCC location $l$ to final delivery point $j$ with regard to goods quantity supplied to the UCC and DV utilisation factor.

$$
T_{1}^{V F P}=\left[\begin{array}{ccc}
t_{11} & \ldots & t_{1 l} \\
\cdot & \cdot & \cdot \\
t_{i 1} & \cdots & t_{i l}
\end{array}\right] ;
$$

$$
\begin{aligned}
T_{2}^{O} & =\left[\begin{array}{ccc}
t_{11} & \ldots & t_{1 j} \\
\cdot & \cdot & \cdot \\
t_{l 1} & \cdots & t_{l j}
\end{array}\right] ; \\
D_{1}^{O} & =\left[\begin{array}{ccc}
d_{11} & \ldots & d_{1 l} \\
\cdot & \cdot & \cdot \\
d_{i 1} & \cdots & d_{i l}
\end{array}\right] ; \\
D_{2}^{O} & =\left[\begin{array}{ccc}
d_{11} & \cdots & d_{1 j} \\
\cdot & \cdot & \cdot \\
d_{l 1} & \cdots & d_{l j}
\end{array}\right] .
\end{aligned}
$$

Matrices of the external costs are also calculated at two levels (to and from the UCC). Finally, the sum of the two values gives the sum of all of the matrix elements in Equations (8) and (9), which results in the particular external costs $c$ when goods are consolidated:

$$
\begin{aligned}
& E C_{c}^{1}=\left(T_{1}^{V F P} \circ D_{1}^{O}\right) e^{V F P} ; \\
& E C_{c}^{2}=\left(T_{2}^{O} \circ D_{2}^{O}\right) e_{c}^{P} .
\end{aligned}
$$

\section{Research results}

Roadside surveys, traffic counting and data enlargement resulted in a total number of 3498 freight vehicles per day (69\% LCVs and 31\% HCVs) finishing trips to the inner city area. Freight vehicles in destination flows carry 10285.12 tonnes of goods a day, of which $38 \%$ is delivered during the peak hours.

The external costs for all of the possible options were calculated with regard to the average trip length. According to the described methodology, we calculated the impact of consolidation on the total external cost of last-mile freight transport in Novi Sad. Unit external costs were transferred for the Serbian environment - the GDP per capita in Serbia is approximately one third of the EU-27 average. The distance travelled by LCVs is 16374.3 veh-km per day, and that travelled by HCVs is 7459.7 veh- $\mathrm{km}$ (Table 1, first column), thus leading to 2791.45 EUR of external costs per day (Table 2, first column) in the urban area of Novi Sad. Furthermore, DVs were introduced, and the impacts of consolidation on the number of vehicle-kilometres and external costs were calculated. In Table 1 (right side), the distances travelled by HCVs, LCVs and DVs are shown for all of the proposed consolidation options. The total number of vehicle-kilometres increases for each consolidation option, but some options significantly reduce the distances travelled by HCVs and LCVs in the urban area. The external costs for all of the suggested consolidation options are shown in Table 2 (right). In contrast to the driving distance, the external costs decrease in the three consolidation scenarios $\left(B_{I+I I}, B_{I I+I I I}\right.$ and $\left.C_{I+I I+I I I}\right)$.

\section{Discussion}

The unit values of external costs given in the IMPACT handbook (Maibach et al. 2008) are intended for EU Member States. A transparent value transfer mecha- 
Table 1. Driving distance - current state (left) and impact of consolidation (right)

\begin{tabular}{|c|c|c|c|c|c|c|c|c|c|c|}
\hline \multirow{2}{*}{$\begin{array}{c}\text { Current driving } \\
\text { distance } \\
\text { [veh-km] } \\
\end{array}$} & & \multirow{2}{*}{ Vehicle type } & & \multicolumn{7}{|c|}{ Consolidation options [veh-km] } \\
\hline & & & & $A_{I}$ & $A_{I I}$ & $A_{I I I}$ & $B_{I+I I}$ & $B_{I+I I I}$ & $B_{I I+I I I}$ & $C_{I+I I+I I I}$ \\
\hline 7459.7 & $\leftarrow$ & $\mathrm{HCV}$ & $\rightarrow$ & 9793.4 & 6076.0 & 8932.6 & 4215.3 & 7560.9 & 2716.8 & 1982.8 \\
\hline 16374.4 & $\leftarrow$ & LCV & $\rightarrow$ & 20832.3 & 9677.7 & 22718.7 & 5495.0 & 18165.7 & 5749.3 & 2828.4 \\
\hline $\mathrm{n} / \mathrm{a}$ & $\leftarrow$ & DV & $\rightarrow$ & 19291.3 & 16425.7 & 25713.0 & 18284.0 & 23708.5 & 23640.2 & 22701.3 \\
\hline 23834.1 & $\leftarrow$ & Total & $\rightarrow$ & 49917.0 & 32179.4 & 57364.3 & 27994.3 & 49435.1 & 32106.3 & 27512.5 \\
\hline
\end{tabular}

Table 2. Daily external costs of urban freight deliveries in Novi Sad - current state (left) and impact of consolidation (right)

\begin{tabular}{|c|c|c|c|c|c|c|c|c|c|c|}
\hline \multirow{2}{*}{$\begin{array}{c}\text { Current } \\
\text { external costs } \\
{[\mathrm{EUR}]}\end{array}$} & & & \multicolumn{7}{|c|}{ External costs of freight consolidation options [EUR] } \\
\cline { 5 - 11 } & & Cost category & & $A_{I}$ & $A_{I I}$ & $A_{I I I}$ & $B_{I+I I}$ & $B_{I+I I I}$ & $B_{I I+I I I}$ & $C_{I+I I+I I I}$ \\
\hline 100.4 & $\leftarrow$ & Climate change & $\rightarrow$ & 166.7 & 105.7 & 174.2 & 83.9 & 149.1 & 80.4 & 66.3 \\
\hline 374.8 & $\leftarrow$ & Air pollution & $\rightarrow$ & 594.7 & 375.6 & 607.6 & 291.8 & 519.1 & 265.5 & 216.2 \\
\hline 233.0 & $\leftarrow$ & Noise costs & $\rightarrow$ & 356.9 & 224.7 & 357.9 & 171.4 & 305.3 & 148.9 & 119.8 \\
\hline 524.8 & $\leftarrow$ & Accidents & $\rightarrow$ & 965.3 & 616.8 & 1055.9 & 512.0 & 906.8 & 538.6 & 453.6 \\
\hline 1407.2 & $\leftarrow$ & Congestion & $\rightarrow$ & 2633.4 & 1661.0 & 2974.4 & 1361.1 & 2553.2 & 1386.4 & 1161.0 \\
\hline 31.7 & $\leftarrow$ & $\begin{array}{c}\text { Soil and water } \\
\text { pollution }\end{array}$ & $\rightarrow$ & 45.6 & 28.6 & 44.2 & 21.0 & 37.6 & 16.6 & 13.0 \\
\hline 119.2 & $\leftarrow$ & $\begin{array}{c}\text { Up- and downstream } \\
\text { processes }\end{array}$ & $\rightarrow$ & 197.4 & 125.1 & 206.0 & 99.2 & 176.3 & 94.8 & 78.1 \\
\hline 2791.4 & $\leftarrow$ & Total & $\rightarrow$ & 4960.2 & 3127.8 & 5420.5 & 2540.7 & 4647.7 & 2531.5 & 2108.3 \\
\hline
\end{tabular}

nism enables the implementation of this methodology in other countries. External cost values obtained by value transfer with regard to GDP per capita are used in this research. These values can be used for policy purposes and for the purposes of this research but have lower accuracy than values obtained with country-specific input values. Therefore, a set of research studies must be conducted in Serbia and other non-EU countries to obtain more accurate assessments of transport externalities.

In this paper, we analysed the impact of different UCC concepts on road freight externalities. Other transport modes were not considered. This approach is considered to be a suitable method for achieving the goal of this particular research because a major part of urban freight demand(s) is met by road transport. However, other modes of transport should not be neglected in cities with more developed alternative delivery modes (e.g., rail or water).

In the presented case study, the calculation of externalities without consolidation resulted in a $0.8 \mathrm{EUR} / \mathrm{veh}$ average external cost produced by a single freight vehicle in the urban area of Novi Sad. As noted in the first section, the literature suggests that forwarding the long-haul traffic from the opposite side of the city to one cross-docking facility on the other side of the city increases traffic flows through or around the urban centre before truck load optimization can take effect. Therefore, seven different UCC options were identified and considered for the city of Novi Sad. Each of the proposed UCC options increases the number of vehicle-kilometres (Table 1) due to the lower capacity of the 'last-mile' DVs. However, options $\mathrm{B}_{\mathrm{I}+\mathrm{II}}$ and $\mathrm{C}_{\mathrm{I}+\mathrm{II}+\mathrm{III}}$ showed the smallest increase in driving distance, indicating that these options have the greatest potential for reducing external costs. In contrast to increasing the total driving distance per vehicle for all of the proposed options, the external costs are lower in the three consolidated delivery options due to the higher vehicle utilisation (Options $B_{I+I I}, B_{I I+I I I}$ and $C_{I+I I+I I I}$, see Table 2$)$. The clear advantage of the options with two consolidation centres $\left(B_{I+I I}\right.$ and $\left.B_{I I+I I I}\right)$ are their lower implementation costs due to the lower number of facilities that need to be constructed or leased. Option $\mathrm{C}_{\mathrm{I}+\mathrm{II}+\mathrm{III}}$ creates the greatest savings in the number of vehicle-kilometres driven by less manageable vehicles on last-mile deliveries (LCVs and HCVs) but requires additional infrastructure and facility investments and initial costs. This option is better as a long-term solution because it reduces operational costs of transport, which could justify a higher one-time investment for implementing the consolidation concept. An enhanced cost-benefit analysis should be conducted for the selected scenarios before implementation.

The implementation of consolidation centres creates many additional possibilities for costs savings, such as using environmentally friendly vehicles for deliveries from consolidation centres, better routing of DVs, implementing time windows for deliveries to congested areas (e.g., central business district), and including valueadded services. The externality reduction could be even higher if these measures were implemented. The congestion during peak hours causes the highest externalities. Therefore, the distribution within the time windows has the greatest potential. Additionally, lowland cities with flat terrain are suitable for using bicycles or electric 
vans to deliver goods from consolidation centres, which could significantly reduce noise, pollution and congestion costs in urban areas. Future research could explore these options in greater depth along with their external costs. Finally, UCCs in this analysis serve only the city area. Due to expected city expansion, UCCs can also be considered to serve the closest city suburbs, which are extremely close to the city near some UCCs, thus contributing to facility and fleet utilisation.

The consolidation strategy should be based on the full social costs. Including transport externalities into the decision-making process creates the most comprehensive picture of the freight transportation costs and enhances decision making. The internalisation of freight transport externalities provides financial resources for additional subsides needed to ensure the success of the consolidation concept. Therefore, this concept implementation should not increase costs solely for the interested parties in goods distribution; instead, it should be covered by all of the citizens, institutions and users that create negative externalities. Recent experiences reveal that city logistics challenges the city authorities, all of the involved stakeholders and citizens in their relationship to freight transportation and requires public-private understanding, collaboration, and innovative partnerships (Crainic et al. 2009a).

The literature and practice show that UCC success is highly related to their dependence on government subsidies during the investment, trial and operational stages (e.g., Van Duin et al. 2010; Verlinde et al. 2012; Janjevic et al. 2013; Allen et al. 2012b). The high external impacts of urban freight transport justifies intervention by the public sector to redress the balance between social cost and social benefit derived from urban freight transport (MDS Transmodal Limited 2012). As noted in the first section, there could be a conflict of interests between the city and particular stakeholders involved in urban freight transport. Therefore, it is of crucial importance that city municipalities recognize the real value of UCCs as well as the related requirements and challenges and support the best concept for the city. Public-private partnerships (PPPs) could be a suitable base for successful business, organizational and functional models; PPPs are also approved as a necessary step in the development of sustainable UCCs or as existing good practice in many cities (e.g., Browne et al. 2005; Allen et al. 2007; Rose-Cherasi 2012; MDS Transmodal Limited 2012; Dablanc et al. 2013; Ninh et al. 2014).

There are some limitations of the research presented in this paper:

- the case study lacks systematic data. Detailed data and time series on the inner city attractors and deliveries are not currently available;

- the impact of the consolidation centre(s) is observed only in terms of load factor improvements and does not consider better vehicle utilisation through reduced empty running due to better planning and routing and consequently reduced external costs;

- only one vehicle type is used for freight delivery from the centre. The fleet structure for freight de- liveries from UCC(s) can be heterogeneous and adapted to various needs of attractors, which should further reduce costs and possibly change the calculated results; also, it is assumed that all observed flows which enter the city go through the UCCs;

- costs other than external were not considered in this paper. From the economic perspective, although a single large UCC may generate more vehicle-kilometres and local congestion, it could also offer better UCC efficiency and lower operational costs. Although this paper focuses on external costs, the final decision is influenced by more than one criterion. The investment and operating costs may significantly affect the results of a full cost-benefit analysis of the consolidation concept. Dablanc (2007) states that the most realistic scenario is to adapt some existing warehouses to UCCs for several stakeholders. This solution could be beneficial for urban planners, the owners of the existing warehouses that may be underutilised, and stakeholders as a whole because this solution requires a minimum investment.

The city of Novi Sad has included only restrictive and incentive measures to protect the inner city from transport externalities to date. Although the city planners have already considered introducing a UCC, these efforts must be extended and include the results presented here. In a more realistic setting, route choice depends on additional parameters (e.g., delivery windows, opening hours, exact location and size of freight receivers, existence and accessibility of loading and unloading zones, traffic congestion, travel and service time). Consideration of these parameters is beyond the scope of this research. However, more precise routing with these constraints should be applied in further analysis and city studies regarding the consolidation concept.

\section{Conclusions}

Today, urban transport planning must balance high expectations from urban logistics to meet city demands with minimum impact on the urban environment. Until recently, urban logistics planning has been rather underestimated by urban traffic planners in Serbia and the surrounding countries. The possibility of introducing a comprehensive infrastructure charging scheme in the EU should be seriously considered by countries in transition, and measures to reduce transport externalities should be considered in the near future.

The assessment of external costs is still highly dependent on the methodology used because transport externalities are not easy to measure. Therefore, the IMPACT methodology (Maibach et al. 2008) for calculating transport externalities should be reassessed, and the unit external costs for countries that intend to join the European Union should be introduced and adjusted for more accurate research. This conclusion is consistent with conclusions presented in the recent research on the public and private passenger transport externalities in Novi Sad, Serbia (Basaric et al. 2015). 
The city characteristics strongly impact the number and locations of UCCs. This paper presents rare research on the city logistics external costs in a developing country that includes options with several UCCs in the city outskirts. The research results confirm that various UCC concepts, related to the number and locations of UCCs, can significantly impact the transport externalities even in medium-sized cities. In the given case study, the solution with three centres has the largest externality reduction, but it may require excessive infrastructure and facility investments and trial costs. The options with one consolidation centre showed higher external costs than those with a combination of several UCCs located where the main interurban flows enter the city.

Internalising extensive transport externalities can significantly affect the city logistics policy. These externalities contribute to selecting the UCC concept because significant investment and operation costs of consolidation centres could be offset by reduced transport external costs in a multi-criteria analysis.

These research results could inspire urban planners to include the external costs of freight transport into urban transport planning cost-benefit analyses in developing countries, especially in cases where planners are considering introducing UCCs in medium-sized cities. Such an approach is an important additional step toward increasing the sustainability of urban freight distribution systems and mitigating negative transport externalities.

Further research regarding urban freight externalities in the city of Novi Sad should focus on creating a database for more accurate calculation of externalities (e.g., locations and sizes of freight attractors, inner-city trip characteristics, existing restrictive urban freight transport measures) and should consider options that include environmentally friendly vehicles for deliveries from UCCs.

\section{Acknowledgements}

Authors would like to thank Prof. Jovanka Pantović from the University of Novi Sad (Serbia) for valuable advices and contributions to this research.

\section{Funding}

This work was supported by the Ministry of Education, Science and Technological Development of the Republic of Serbia [Grant No. TR36030].

\section{Disclosure statement}

Authors of this publication have no competing financial, professional, or personal interests from other parties to disclose.

\section{References}

Allen, J.; Browne, M.; Cherrett, T. 2012a. Investigating relationships between road freight transport, facility location, logistics management and urban form, Journal of Transport Geography 24: 45-57.

https://doi.org/10.1016/j.jtrangeo.2012.06.010
Allen, J.; Browne, M.; Woodburn, A.; Leonardi, J. 2012b. The role of urban consolidation centres in sustainable freight transport, Transport Reviews 32(4): 473-490.

https://doi.org/10.1080/01441647.2012.688074

Allen, J.; Thorne, G.; Browne, M. 2007. Good Practice Guide on Urban Freight Transport. BEST Urban Freight Solutions (BESTUFS). Rijswijk, Netherlands. 84 p. Available from Internet: http://www.bestufs.net/download/BESTUFS_II/ good_practice/English_BESTUFS_Guide.pdf

Ansbro, D.; Wang, Q. 2013. A facility location model for socioenvironmentally responsible decision-making, Journal of Remanufacturing 3(5): 1-13.

https://doi.org/10.1186/2210-4690-3-5

Basaric, V.; Djoric, V.; Jevdjenic, A.; Jovic, J. 2015. Efficient methodology for assessment of targets and policy measures for sustainable mobility systems, International Journal of Sustainable Transportation 9(3): 217-226.

https://doi.org/10.1080/15568318.2012.756088

Bhattacharya, A.; Kumar, S. A.; Tiwari, M. K.; Talluri, S. 2014. An intermodal freight transport system for optimal supply chain logistics, Transportation Research Part C: Emerging Technologies 38: 73-84. https://doi.org/10.1016/j.trc.2013.10.012

Browne, M.; Allen, J.; Leonardi, J. 2011. Evaluating the use of an urban consolidation centre and electric vehicles in central London, IATSS Research 35(1): 1-6. https://doi.org/10.1016/j.iatssr.2011.06.002

Browne, M.; Sweet, M.; Woodburn, A.; Allen, J. 2005. Urban Freight Consolidation Centres: Final Report. Project Report. Transport Studies Group, University of Westminster for the Department for Transport, London, UK. 191 p.

Browne, M.; Woodburn, A.; Allen, J. 2007. The role of urban consolidation centres for different business sectors, in 11th World Conference on Transport Research Society (WCTRS), 24-28 June 2007, Berkeley, CA, US, 1-20.

Crainic, T. G.; Ricciardi, N.; Storchi, G. 2004. Advanced freight transportation systems for congested urban areas, Transportation Research Part C: Emerging Technologies 12(2): 119-137. https://doi.org/10.1016/j.trc.2004.07.002

Crainic, T .G.; Gendreau, M.; Potvin, J.-Y. 2009a. Intelligent freight-transportation systems: Assessment and the contribution of operations research, Transportation Research Part C: Emerging Technologies 17(6): 541-557. https://doi.org/10.1016/j.trc.2008.07.002

Crainic, T. G.; Ricciardi, N.; Storchi, G. 2009b. Models for evaluating and planning city logistics systems, Transportation Science 43(4): 432-454. https://doi.org/10.1287/trsc.1090.0279

Dablanc, L. (Ed.). 2011. City Logistics Best Practices: a Handbook for Authorities. Sustainable Urban Goods Logistics Achieved by Regional and Local Policies (SUGAR), Bologna, Emilia-Romagna Region, Italy. 276 p. https://doi.org/10.13140/2.1.5149.5201

Dablanc, L. 2007. Goods transport in large European cities: Difficult to organize, difficult to modernize, Transportation Research Part A: Policy and Practice 41(3): 280-285. https://doi.org/10.1016/j.tra.2006.05.005

Dablanc, L.; Giuliano, G.; Holliday, K.; O’Brien, T. 2013. Best practices in urban freight management: lessons from an international survey, Transportation Research Record: Journal of the Transportation Research Board 2379: 29-38. https://doi.org/10.3141/2379-04

De Assis Correia, V.; De Oliveira, L. K.; Guerra, A. L. 2012. Economical and environmental analysis of an urban con- 
solidation center for Belo Horizonte City (Brazil), Procedia - Social and Behavioral Sciences 39: 770-782. https://doi.org/10.1016/j.sbspro.2012.03.146

Ehmke, J. F. 2012. City Logistics, International Series in Operations Research \& Management Science 177: 9-22. https://doi.org/10.1007/978-1-4614-3628-7_2

EC. 1995. Towards Fair and Efficient Pricing in Transport: Policy Options for Internalising the External Costs of Transport in the European Union. Available from Internet: http://europa.eu/documents/comm/green_papers/pdf/com95_691_ en.pdf

EC. 2003. External Costs: Research Results on Socio-Environmental Damages Due to Electricity and Transport. 28 p. Available from Internet: https://ec.europa.eu/research/energy/pdf/externe_en.pdf

Filippi, F.; Nuzzolo, A.; Comi, A.; Site, P. D. 2010. Ex-ante assessment of urban freight transport policies, Procedia - Social and Behavioral Sciences 2(3): 6332-6342. https://doi.org/10.1016/j.sbspro.2010.04.042

Forkenbrock, D. J. 1999. External costs of intercity truck freight transportation, Transportation Research Part A: Policy and Practice 33(7-8): 505-526.

https://doi.org/10.1016/S0965-8564(98)00068-8

Gallo, M. 2010. Estimating external costs of transportation in regional areas: using available statistical data the case of the region of Campania, TeMA: Journal of Mobility, Land Use and Environment 3: 107-120.

Gentile, G.; Vigo, D. 2013. Movement generation and trip distribution for freight demand modelling applied to city logistics, European Transport $\backslash$ Trasporti Europei 54(Paper No 6): 1-27.

Gonzalez-Feliu, J.; Salanova Grau, J.-M. 2014. How the location of urban consolidation and logistics facility has an impact on the delivery costs? An accessibility analysis, in Transport Research Arena (TRA) 5th Conference: Transport Solutions from Research to Deployment, 14-17 April 2014, Paris, France, 1-7.

Gonzalez-Feliu, J.; Salanova Grau, J.-M.; Beziat, A. 2014. A location-based accessibility analysis to estimate the suitability of urban consolidation facilities, International Journal of Urban Sciences 18(2): 166-185.

https://doi.org/10.1080/12265934.2014.930673

Güler, H. 2014. An empirical modelling framework for forecasting freight transportation, Transport 29(2): 185-194. https://doi.org/10.3846/16484142.2014.930927

Herzog, B. O. 2011. Urban Freight in Developing Cities. Module 1g: Sustainable Transport: A Sourcebook for Policy-Makers in Developing Cities. Transport Policy Advisory Services, Federal Ministry for Economic Cooperation and Development. Eschborn, Germany. 62 p.

Janjevic, M.; Kaminsky, P.; Ndiaye, A. B. 2013. Downscaling the consolidation of goods - state of the art and transferability of micro-consolidation initiatives, European Transport \Trasporti Europei 54(Paper No 4): 1-23.

Javno preduzeće 'Urbanizam'. 2004. Studija o uslovima $i$ opravdanosti izgradnje robno transportnog centra u Novom $S a d u$, Zavod za Urbanizam, Novi Sad. 115 p. Available from Internet: http://www.nsurbanizam.rs/sites/default/ files/1522-Studija\%20o\%20uslovima\%20i\%20opravdanosti\%20izgradnje\%20RTC.pdf (in Serbian)

Javno preduzeće 'Urbanizam'. 2009. Saobraćajna studija grada Novog Sada sa dinamikom uređenja saobraćaja - NOSTRAM, Zavod za Urbanizam, Novi Sad. 94 p. Available from Internet: http://www.nsurbanizam.rs/sites/default/ files/1770\%20Saobracajna\%20studija-NOSTRAM-.pdf (in Serbian).

Konstantinopoulou, L. 2010. D1.1 Trends of Urban Logistics in Europe 27. Project Citylog Sustainability and Efficiency of City Logistics, FP7. Grant Agreement number: 232756. $70 \mathrm{p}$.

Korzhenevych, A.; Dehnen, N.; Bröcker, J.; Holtkamp, M.; Meier, H.; Gibson, G.; Varma, A.; Cox, V. 2014. Update of the Handbook on External Costs of Transport. Report for the European Commission: DG MOVE: Ricardo-AEA/R/ ED57769, London. 139 p. Available from Internet: https:// ec.europa.eu/transport/sites/transport/files/themes/sustainable/studies/doc/2014-handbook-external-costs-transport.pdf

Kostreš, M.; Atanacković-Jeličić, J. 2011. Sociopolitical changes and city growth - a case study of Novi Sad, Serbia, in Proceedings of 16th International Conference on Urban Planning and Regional Development in the Information Society (REAL CORP 2011), 18-20 May 2011, Essen, Germany, 1383-1387.

Lewis, A.; Fell, M.; Palmer, D. 2010. Freight Consolidation Centre Study. Department for Transport, London, UK.

Maibach, M.; Schreyer, C.; Sutter, D.; Van Essen; H. P.; Boon, B. H.; Smokers, R.; Schroten, A.; Doll, C.; Pawlowska, B.; Bak, M. 2008. Handbook on Estimation of External Costs in the Transport Sector. Produced within the study Internalisation Measures and Policies for All external Cost of Transport (IMPACT), Version 1.1. Delft, Netherlands. 336 p. Available from Internet: https://ec.europa.eu/transport/sites/transport/files/themes/sustainable/doc/2008_ costs_handbook.pdf

Marcucci, E.; Danielis, R. 2008. The potential demand for a urban freight consolidation centre, Transportation 35(2): 269-284. https://doi.org/10.1007/s11116-007-9147-3

MDS Transmodal Limited. 2012. DG MOVE European Commission: Study on Urban Freight Transport. Final Report. Chester, UK. 156 p. Available from Internet: https:// ec.europa.eu/transport/sites/transport/files/themes/urban/ studies/doc/2012-04-urban-freight-transport.pdf

Ninh, P.; Bentzen, K.; Laugesen, M. S. 2014. Why Should Transportation Companies Join Public Private Partnership (PPP) Proposed by the Public Sector to Support the Implementation Process of Freight Electric Vehicles (FEVs) In Copenhagen Municipality: Report. Association of Danish Transport and Logistics Centres (FDT), Aalborg, Denmark. 60 p. Available from Internet: http://e-mobility-nsr.eu/fileadmin/ user_upload/downloads/info-pool/Activty_7.4.4_Report_ on_PPPs.pdf

Panebianco, M.; Zanarini, M. (Eds.). 2005. City Ports Project: Interim Report. Bologna, Emilia-Romagna Region, Italy. 209 p.

Rose-Cherasi, I. 2012. L 2.1: State of the Art Report 'Urban Logistics Practices'. Project No 60R13620 (Version 4). SINTEF: Technology and Society. Trondheim, Norway. $71 \mathrm{p}$.

Russo, F.; Comi, A. 2010. A classification of city logistics measures and connected impacts, Procedia - Social and Behavioral Sciences 2(3): 6355-6365.

https://doi.org/10.1016/j.sbspro.2010.04.044

Russo, F.; Comi, A. 2012. City characteristics and urban goods movements: a way to environmental transportation system in a sustainable city, Procedia - Social and Behavioral Sciences 39: 61-73.

https://doi.org/10.1016/j.sbspro.2012.03.091 
Statistical Office of the Republic of Serbia. 2012. Ethnicity: Data by Municipalities and Cities. 2011 Census of Population, Households and Dwellings in the Republic of Serbia, Belgrade. 121 p. Available from Internet: http://pod2.stat. gov.rs/ObjavljenePublikacije/G2012/pdf/G20124001.pdf

Stojanović, Đ.; Basarić, V.; Gajić, V. 2011. The impact of freight transport on urban noise, in Proceedings of the 3rd International Conference "Towards a Human City", 27-28 October 2011, Novi Sad, Serbia, 261-267.

Van den Bossche, M.; Beekman, R.; Baanders, B.; Scholten, B.; Schroten, A; Van Essen, H. 2012. Study on Urban Aspects of the Internalisation of External Costs - MOVE/B4/3101/2011. Final Report. Rotterdam, Netherlands. 228 p. Available from Internet: https://ec.europa.eu/transport/sites/ transport/files/themes/urban/studies/doc/2012-study-onurban-aspects-of-the-internalisation-of-external-costs.pdf

Van Duin, J. H. R.; Quak, H.; Muñuzuri, J. 2010. New challenges for urban consolidation centres: a case study in the Hague, Procedia - Social and Behavioral Sciences 2(3): 6177-6188. https://doi.org/10.1016/j.sbspro.2010.04.029

Van Duin, J. H. R.; Van Kolck, A.; Anand, N.; Tavasszy, L. A.; Taniguchi, E. 2012. Towards an agent-based modelling approach for the evaluation of dynamic usage of urban distribution centres, Procedia - Social and Behavioral Sciences 39: 333-348. https://doi.org/10.1016/j.sbspro.2012.03.112

Van Essen, H.; Nelissen, D.; Smit, M.; Van Grinsven, A.; Aarnink, S.; Breemersch, T.; Martino, A.; Rosa, C.; Parolin, R.; Harmsen, J. 2012. An Inventory of Measures for Internalising External Costs in Transport. Final Report of Specific Contract MOVE/A3/350-2010 Impact Assessments and Evaluations (Ex-Ante, Intermediate and ExPost) in the Field of the Transport. 127 p. Available from Internet: https://ec.europa.eu/transport/sites/transport/ files/themes/sustainable/studies/doc/2012-11-inventorymeasures-internalising-external-costs.pdf

Van Rooijen, T.; Quak, H. 2010. Local impacts of a new urban consolidation centre - the case of Binnenstadservice.nl, Procedia - Social and Behavioral Sciences 2(3): 5967-5979. https://doi.org/10.1016/j.sbspro.2010.04.011

Veličković, M.; Stojanović, Đ.; Basarić, V. 2011. An approach to city logistics terminal location problem in Novi Sad, Scientific Bulletin of the "Politehnica" University of Timişoara: Transactions on Mechanics 56(70): 93-98.

Veličković, M.; Stojanović, Đ.; Basarić, V. 2014. The assessment of pollutants emissions within sustainable urban freight transport development: the case of Novi Sad, Thermal Science 18(1): 307-321. https://doi.org/10.2298/TSCI120808037V

Verlinde, S.; Macharis, C.; Witlox, F. 2012. How to consolidate urban flows of goods without setting up an urban consolidation centre?, Procedia - Social and Behavioral Sciences 39: 687-701. https://doi.org/10.1016/j.sbspro.2012.03.140

Wolpert, S.; Reuter, C. 2012. Status quo of city logistics in scientific literature: systematic review, Transportation Research Record: Journal of the Transportation Research Board 2269: 110-116. https://doi.org/10.3141/2269-13 